Bond University

Research Repository

\title{
Industry momentum: an exchange-traded funds approach
}

Vanstone, Bruce J; Hahn, Tobias; Earea, Dean

Published in:

Accounting and Finance

DOI:

10.1111/acfi. 12724

Licence:

Other

Link to output in Bond University research repository.

Recommended citation(APA):

Vanstone, B. J., Hahn, T., \& Earea, D. (2021). Industry momentum: an exchange-traded funds approach. Accounting and Finance, 61(3), 4007-4024. https://doi.org/10.1111/acfi.12724

\footnotetext{
General rights

Copyright and moral rights for the publications made accessible in the public portal are retained by the authors and/or other copyright owners and it is a condition of accessing publications that users recognise and abide by the legal requirements associated with these rights.
}

For more information, or if you believe that this document breaches copyright, please contact the Bond University research repository coordinator. 


\section{Industry Momentum: An Exchange- Traded Funds approach}

Author Details:

First Author and Corresponding Author: Bruce J. Vanstone, Bond University, Australia ${ }^{1}$

Second Author: Tobias Hahn

Third Author: Dean Earea, Bond University, Australia

$\underline{\text { Abstract }}$

Stock price momentum is a well-documented anomaly in many of the world's equity markets, and refers to the excess returns due to buying(selling) past winner(loser) stocks. Industry momentum refers to the excess returns due to buying(selling) stocks from past winner(loser) industries, and has been demonstrated to be more profitable than individual stock momentum in the US. We investigate whether industry momentum can be captured by investing within a much smaller set of Sector ETFs. We find that the performance and character of Sector ETFbased industry momentum portfolios is very different to stock momentum portfolios, and the strong performance of an unexpected group of Sector ETF momentum portfolios remain robust after controlling for risk.

\section{Keywords}

Momentum, ETF, Economic viability

\footnotetext{
${ }^{1}$ Bruce Vanstone, Email: bvanston@bond.edu.au, Phone: +61 7 55953394, Address: Bond University, Gold Coast, QLD, 4229, Australia
} 


\section{$\underline{\text { JEL Classification }}$}

G11

This is the peer reviewed version of the following article: Vanstone, B. J., Hahn, T., \& Earea, D. (2020). Industry momentum: an exchange-traded funds approach. Accounting and Finance, which has been published in final form at https://doi.org/10.1111/acfi.12724.

This article may be used for non-commercial purposes in accordance with Wiley Terms and Conditions for Use of Self-Archived Versions. 


\section{Introduction}

As an investment anomaly, momentum refers to the abnormal returns due to buying past winners and selling past losers. In their seminal work, Jegadeesh \& Titman (1993) (hence referred to as $\mathrm{J} \& \mathrm{~T}$ ) document momentum as a zero cost investment strategy, in which shorting loser stocks provides funds for buying winner stocks.

This paper focuses on industry momentum, as originally documented by Moskowitz and Grinblatt (Moskowitz and Grinblatt 1999) (hence referred to as M\&G). Industry momentum is defined as the abnormal returns due to buying stocks from past winner industries and selling stocks from past loser industries. M\&G document a strong and prevalent momentum effect in the industry components of stock returns which subsumes much of the individual stock momentum anomaly.

In particular, M\&G document:

1. Industry portfolios exhibit significant momentum even after controlling for size, book-to-market equity, individual stock momentum, the cross-sectional dispersion in mean returns, and potential microstructure influences

2. Momentum profits from individual equities are significantly weaker and often statistically insignificant after adjusting for industry effects

3. Industry momentum strategies are more profitable than individual stock momentum strategies

4. Industry momentum strategies are robust to various specifications and methodologies, and appear profitable even among the largest, most liquid stocks

5. Profitability of industry momentum over intermediate horizons is predominantly driven by long positions, in contrast to individual stock momentum, which is often driven by selling past loser, often less liquid stocks

6. Unlike stocks, industry momentum is strongest at short term (1 month) horizon, tends to dissipate around 12 months, and reverses at longer horizons.

M\&G form 20 value-weighted industry portfolios based on 2-digit SIC codes using CRSP and Compustat monthly data between July 1963 and July 1995. They then further form 6/6 momentum portfolios by investing long(short) in the top(bottom) 3 industries. M\&G suggest 
individual stock momentum is not very well diversified as winners and losers tend to be from the same industry, and conclude that industry-based strategies are more profitable and more implementable. Finally, $M \& G$ raise the question of the extent to which the transaction costs incurred through buying and selling many stocks may affect returns.

The motivation of this paper is to investigate the investment performance of industry momentum strategies using Exchange Traded Funds (ETFs), and to determine whether the beneficial aspects of industry momentum can be captured using ETFs with a substantially reduced turnover and implementation cost.

ETFs represent a cost effective approach to buying baskets of stocks, are highly liquid, and are historically available as sector-based investment products (State Street Global Advisors 2016). Thus, buying/selling Sector ETFs rather than the equity members of industry groupings appears to be offer a potentially lower cost approach to implementing investment strategies based on industry momentum with substantially greater capacity for investment.

Using ETFs to assess the performance of industry momentum has a number of distinct benefits (Madura and Ngo 2008). ETFs can represent specific sectors or indices which appeals to investors and leads directly to implementing industry momentum strategies; ETF prices are tied to NAV (unlike closed-end funds); ETFs are structured as trusts to minimize tax distributions; ETFs provide greater tax benefits as they generate fewer capital gains as a result of lower turnover (which only reflects changes in underlying indexes); expenses are low due to passive investment approach (as opposed to the active management style of mutual funds); ETFs can be traded any time the exchange is open (unlike mutual funds); ETFs can be used for shorting and ETFs are widely traded, resulting in relatively low transaction costs and lower management fees, particularly for index ETFs. 
The paper proceeds as follows: Section 2 provides a detailed literature review covering prior work in industry momentum addressing potential momentum sources, differences from stock momentum, and empirical tests of performance using indices, mutual funds, and ETFs. Section 3 details the methodology, briefly covering the standard J\&T (Jegadeesh and Titman 1993) momentum implementation framework. Section 4 details the results and analysis, whilst Section 5 presents concluding comments.

\section{Literature Review}

There is now considerable academic evidence to support the existence of the momentum anomaly. Abnormal momentum returns have been demonstrated in US Equities (Jegadeesh and Titman 1993; Asness 1994), foreign markets and emerging markets (Rouwenhorst 1998; Rouwenhorst 1999; Chan, Hameed, and Tong 2000; Griffin, Ji, and Martin 2004; Griffin, Ji, and Martin 2003; Vanstone and Hahn 2015), commodities (Miffre and Rallis 2007), real estate (Stevenson 2002; Beracha and Skiba 2011), FX (Menkhoff et al. 2012; Okunev and White 2003), indices (Bhojraj and Swaminathan 2006; Asness, Liew, and Stevens 1997), government (Asness, Moskowitz, and Pedersen 2013) and corporate bonds (Jostova et al. 2013). Momentum has been demonstrated across asset classes (Blitz and Vliet 2008), countries (Naranjo and Porter 2010) styles (Asness, Moskowitz, and Pedersen 2013), and within industries (Moskowitz and Grinblatt 1999). There is also considerable evidence that momentum investment has gained traction within the funds management community (Burch and Swaminathan 2001; Boni and Womack 2006; Breloer, Scholz, and Wilkens 2014).

Prior work on industry momentum has focused on potential sources of abnormal returns, and the selection and performance assessment of possible investment vehicles. 
Primary sources of industry momentum returns are uncertain, and proposed explanations mainly relate to either delayed reaction to the traditional Fama-French factors (Du and Denning 2005), firm productivity (Chen, Wu, and Zhang 2007), time-varying serial correlation (Du and Watkins 2007), industry growth (Safieddine and Sonti 2007), structural changes (Chui, Titman, and Wei 2003; Kalotychou, Staikouras, and Zhao 2014) and herding (Demirer, Lien, and Zhang 2015).

In their original work using US data, M\&G documented a strong and prevalent momentum effect in the industry component of stock returns which accounts for much of the individual stock momentum anomaly. As industries themselves are not directly investible, $M \& G$ invested in the constituent members of industries. This approach is reasonably common (Scowcroft and Sefton 2005), including for foreign countries (Gupta, Locke, and Scrimgeour 2010; Li et al. 2014; Nijman, Swinkels, and Verbeek 2004; Narayan et al. 2014). Alternatives to investing in the stocks within an industry grouping include investing in indices (Menkhoff and Schmeling 2004), mutual funds (O'Neal 2000; Avramov and Wermers 2006; Kaminsky, Lyons, and Schmukler 2004; Sapp 2011; Madura and Bers 2002) or ETFs (Madura and Ngo 2008; De Jong and Rhee 2008; Velissaris 2010; Dolvin and Kirby 2011; Dimkpah and Ngassam 2013; Andreu, Swinkels, and Tjong-A-Tjoe 2013; Tse 2015).

Typically, within industry momentum research using indices, actual index returns have been used to calculate returns to industry momentum portfolios, and as indices are untradeable, this leads to unrealistic results. The primary disadvantage to implementing industry momentum using mutual funds is that they are generally actively managed, and therefore, may not accurately represent the returns of the relevant industries. Prior research suggests ETFs appear to provide the best investment vehicle, they are tradeable, deep, and are designed to reflect the underlying industry or index. 
Madura \& Ngo (Madura and Ngo 2008) attempt to provide a rationale for understanding how momentum may occur in an ETF context. To the extent that momentum is a result of correction to low or high stock fundamentals, then it is unlikely to be found in ETFs. If momentum is related to under-reaction, then it needs news, which is more apparent for stocks than ETFs. To the extent that momentum is based on stock selection criteria (like in an active mutual fund), then ETFs are passive so there is no active stock selection. The authors speculate that momentum could only possibly exist within ETFs due to herding behaviour.

\section{Methodology}

The security universe for this study is the nine S\&P500 Sector ETFs from State Street (State Street Global Advisors 2016). Data are sourced from Bloomberg and cover the period January 2000 to December 2015 inclusive. We follow the traditional J\&T methodology by creating monthly overlapping portfolios, formed according to the $\mathrm{J} / \mathrm{S} / \mathrm{K}$ methodology. Conceptually, in constructing overlapping portfolios, a portfolio with $\mathrm{K}$ months holding period at time $t$ is a composite portfolio consisting of K subparts. Each month, 1/K holdings are revised, meaning that at the end of month $t+1$, the portfolio previously constructed at time t+1-K will be liquidated and replaced with a new portfolio. Unlike the traditional decile portfolios commonly formed in tests of stock momentum, this paper buys(sells) the highest(lowest) ranked ETF over the historical $\mathrm{J}$ month period. Zero cost portfolios are formed for the subsequent K months. For more details on the overlapping portfolio approach, see Jegadeesh \& Titman (Jegadeesh and Titman 1993).

As in the majority of momentum literature, we calculate and present raw monthly returns and present a more detailed analysis of a specific portfolio pair. In traditional stock momentum, 
this would be the 6/0/6 and 6/1/6 portfolios, however, our analysis suggests these are not the appropriate portfolios to analyze for Sector ETF momentum.

The basic statistical properties of the State Street ETF returns used in this study are shown in Table 1. Table 2 shows the yearly turnover in these ETFs, indicating their market depth and hence opportunity to accomodate larger funds.

\begin{tabular}{llrrrrrr} 
Sectors & Ticker & Average & Volatility & Skewness & Kurtosis & Min & Max \\
\hline Materials & XLB & 0.74 & 6.32 & 0.05 & 1.43 & -22.40 & 24.71 \\
Energy & XLE & 0.85 & 6.31 & -0.13 & 0.47 & -18.80 & 19.14 \\
Financials & XLF & 0.37 & 6.33 & -0.44 & 2.83 & -26.20 & 21.79 \\
Industrials & XLI & 0.68 & 5.41 & -0.28 & 1.48 & -18.25 & 18.07 \\
Information Tech & XLK & 0.40 & 6.99 & -0.32 & 1.48 & -24.91 & 24.77 \\
Consumer Staples & XLP & 0.56 & 3.53 & -0.82 & 1.32 & -12.61 & 9.13 \\
Utilities & XLU & 0.59 & 4.37 & -0.70 & 1.31 & -14.72 & 13.22 \\
Health & XLV & 0.67 & 4.05 & -0.45 & 0.99 & -14.48 & 11.60 \\
Consumer Discr. & XLY & 0.76 & 5.40 & -0.15 & 0.79 & -17.63 & 18.52
\end{tabular}

Table 1 Summary ETF Statistics

\begin{tabular}{rrrrrrrrrr} 
& XLB & XLE & XLF & XLI & XLK & XLP & XLU & XLV & XLY \\
\hline 1999 & 312 & 876 & 1002 & 241 & 5455 & 361 & 131 & 181 & 198 \\
2000 & 362 & 2031 & 2453 & 340 & 6842 & 711 & 465 & 296 & 758 \\
2001 & 364 & 2247 & 3554 & 322 & 5327 & 489 & 288 & 195 & 949 \\
2002 & 1639 & 1644 & 10296 & 834 & 4390 & 660 & 743 & 542 & 1448 \\
2003 & 1941 & 1993 & 10284 & 1472 & 2427 & 800 & 1860 & 808 & 1133 \\
2004 & 5381 & 13296 & 18860 & 3669 & 2659 & 2001 & 3381 & 2724 & 2352 \\
2005 & 11704 & 140659 & 43735 & 5363 & 4484 & 3949 & 10032 & 5058 & 5554 \\
2006 & 22237 & 266313 & 53382 & 9597 & 8912 & 7508 & 19123 & 8461 & 8695 \\
2007 & 52652 & 318306 & 297032 & 31417 & 14900 & 11329 & 42410 & 14799 & 22013 \\
2008 & 100670 & 501534 & 761124 & 62593 & 33193 & 24433 & 43101 & 29318 & 43071 \\
2009 & 56794 & 267177 & 386456 & 56034 & 32132 & 28266 & 37649 & 35914 & 38147 \\
2010 & 83734 & 230821 & 329982 & 107545 & 57936 & 39322 & 41167 & 52307 & 59709 \\
2011 & 115610 & 341129 & 298758 & 161346 & 71648 & 60116 & 55122 & 79328 & 74125
\end{tabular}

This is the peer reviewed version of the following article: Vanstone, B. J., Hahn, T., \& Earea, D. (2020). Industry momentum: an exchange-traded funds approach. Accounting and Finance, which has been published in final form at https://doi.org/10.1111/acfi.12724. 


$\begin{array}{rrrrrrrrrr}2012 & 71353 & 208761 & 226847 & 114458 & 61329 & 46951 & 54879 & 51058 & 62419 \\ 2013 & 60837 & 197917 & 205932 & 102716 & 56175 & 80543 & 87962 & 79516 & 74325 \\ 2014 & 69529 & 322137 & 197402 & 132148 & 73133 & 82158 & 121194 & 128430 & 100215 \\ 2015 & 62881 & 332382 & 213668 & 145398 & 99613 & 104534 & 138279 & 207364 & 123659\end{array}$

Table 2 Dollar turnover in ETFs by year (millions)

\section{Results}

The primary motivation of this paper is to investigate the investment performance of momentum strategies using Sector ETFs, and to determine whether the beneficial performance aspects of industry stock momentum can be captured using these highly liquid ETFs

\subsection{Momentum Returns}

We use the $\mathrm{J} / \mathrm{S} / \mathrm{K}$ notation to describe the formation of the ETF momentum portfolios, with $\mathrm{J} / \mathrm{S} / \mathrm{K}$ ranging from $[3,6,9,12,15,18,21,24] /[0,1] /[3,6,9,12,15,18,21,24]$, leading to a total of 128 portfolios. $^{2}$

Table 4 presents the Winner-Minus-Loser (WML) monthly mean returns for each of the 64 momentum portfolios with S=0 (no skipped month) and Table 4 presents the same data for the momentum portfolios with $S=1$. Each $\mathrm{J} / \mathrm{K}$ cell presents the raw mean return (WML) along with the respective $t$-statistics and $p$-values for that $\mathrm{J} / \mathrm{K}$ portfolio combination. In all results presented $* *$ represents statistical significance at the $1 \%$ level and $*$ represents statistical significance at the 5\% level. Table 3 and Table 4 confirm the presence of the momentum effect among the Sector ETFs.

\footnotetext{
${ }^{2}$ In producing these results, we long(short) the top(bottom) Sector ETF. We also calculate performance for forming equally weighted momentum portfolios by taking long(short) positions in the top 2(bottom 2) Sector ETFs and confirm that our conclusions are not materially affected. Results are available on request from the authors.
} 
Stock momentum is normally considered as a medium-term effect, with $\mathrm{J}$ \& $\mathrm{K}$ usually profitably ranging between 6 and 18 months. In such cases, the 6/6 portfolio normally represents the typical result. Table 3 and Table 4 show a completely different profile. Although there is a significant spike at the 6/6 portfolio in both tables, Table 6 later shows that the abnormal return at the 6/6 portfolios does not survive HAC corrected risk adjustment. Based on the academic evidence surrounding stock momentum, the natural choice would be to invest in 6/6 portfolios. In strong contrast to typical stock momentum portfolios, the real area of interest here is the portfolios formed with a much longer lookback and holding period. As the length of the lookback period increases, the raw returns monotonically increase. As the length of the holding period increases, the raw returns monotonically increase, in contrast with the findings of M\&G where industry momentum within stocks is strongest at the short term horizons.

Further, it appears there is no real distinction in returns between portfolios that skip a month $(S=1)$ and those that do not $(S=0)$ between their ranking and formation periods. The $S=1$ portfolios are certainly more forgiving from a practical perspective, allowing a portfolio manager more than enough time to form the required portfolios, and also satisfying market microstructure concerns. 


\begin{tabular}{|c|c|c|c|c|c|c|c|c|}
\hline & K3 & K6 & $\mathrm{K} 9$ & K12 & K15 & K18 & K21 & K24 \\
\hline $\mathrm{J} 3$ & $-0.0005-0.1876(0.8514)$ & $0.00090 .4779(0.6332)$ & $0.00130 .7951(0.4276)$ & $0.00060 .3915(0.6959)$ & $-0.0007-0.5563(0.5787)$ & $-0.0011-0.9408(0.3480)$ & $-0.0006-0.5434(0.5875)$ & $-0.0006-0.6112(0.5419)$ \\
\hline $\mathrm{J} 6$ & $0.00170 .5974(0.5509)$ & $0.00412 .0783(0.0390)$ * & $0.00321 .9763(0.0496) *$ & $0.00201 .3581(0.1761)$ & $0.00090 .6719(0.5025)$ & $0.00090 .7397(0.4605)$ & $0.00111 .0345(0.3023)$ & $0.00111 .0487(0.2958)$ \\
\hline ر9 & $0.00351 .2005(0.2314)$ & $0.00140 .6765(0.4995)$ & $0.00040 .2075(0.8359)$ & $-0.0012-0.7942(0.4281)$ & $-0.0009-0.7071(0.4804)$ & $-0.0008-0.6846(0.4945)$ & $-0.0008-0.7053(0.4816)$ & $-0.0002-0.2063(0.8368)$ \\
\hline $\mathrm{J} 12$ & $0.00220 .7550(0.4512)$ & $0.00190 .9307(0.3532)$ & $0.00080 .4386(0.6615)$ & $0.00080 .5149(0.6072)$ & $0.00050 .4049(0.6861)$ & $-0.0001-0.0598(0.9524)$ & $0.00030 .2640(0.7921)$ & $0.00100 .9378(0.3497)$ \\
\hline J15 & $0.00140 .4620(0.6447)$ & $0.00050 .2507(0.8024)$ & $0.00150 .9782(0.3293)$ & $0.00130 .9639(0.3364)$ & $0.00080 .6744(0.5010)$ & $0.00121 .0591(0.2911)$ & $0.00131 .2670(0.2069)$ & $0.00171 .6656(0.0977)$ \\
\hline $\mathrm{J} 18$ & $0.00230 .7639(0.4459)$ & $0.00382 .0101(0.0459) *$ & $0.00483 .2645(0.0013)$ ** & $0.00413 .2687(0.0013) * *$ & $0.00383 .2535(0.0014)^{* *}$ & $0.00353 .2721(0.0013)^{* *}$ & $0.00363 .5030(0.0006) * *$ & $0.00373 .8355(0.0002)$ ** \\
\hline $\mathrm{J} 21$ & $0.00491 .7636(0.0795)$ & $0.00553 .0883(0.0023)$ ** & $0.00543 .9199(0.0001) * *$ & $0.00544 .4973(0.0000)^{* *}$ & $0.00504 .7327(0.0000)^{* *}$ & $0.00485 .0367(0.0000) * *$ & $0.00475 .2741(0.0000) * *$ & $0.00505 .9759(0.0000) * *$ \\
\hline$J 24$ & $0.00552 .0122(0.0457) *$ & $0.00573 .1637(0.0018) * *$ & $0.00634 .5053(0.0000) * *$ & $0.00594 .8880(0.0000)^{* *}$ & $0.00565 .3599(0.0000) * *$ & $0.00555 .9382(0.0000)^{* *}$ & $0.00566 .6161(0.0000) * *$ & $0.00587 .5057(0.0000)^{* *}$ \\
\hline
\end{tabular}

Table 3 WML Mean Returns (S=0)

\begin{tabular}{|c|c|c|c|c|c|c|c|c|}
\hline & K3 & K6 & K9 & K12 & K15 & K18 & $\mathrm{K} 21$ & K24 \\
\hline 13 & $0.00070 .2377(0.8123)$ & $0.00070 .3557(0.7225)$ & $0.00140 .8223(0.4120)$ & $0.00000 .0130(0.9897)$ & $-0.0012-0.8814(0.3793)$ & $-0.0010-0.8251(0.4104)$ & $-0.0005-0.5120(0.6093)$ & $-0.0007-0.7094(0.4790)$ \\
\hline J6 & $0.00321 .0870(0.2784)$ & $0.00472 .4248(0.0163) *$ & $0.00311 .8677(0.0634)$ & $0.00140 .9805(0.3281)$ & $0.00080 .6529(0.5147)$ & $0.00110 .9813(0.3278)$ & $0.00141 .2527(0.2120)$ & $0.00111 .1053(0.2706)$ \\
\hline ور & $0.00240 .8293(0.4080)$ & $0.00040 .1789(0.8582)$ & $-0.0006-0.3541(0.7237)$ & $-0.0013-0.8859(0.3769)$ & $-0.0011-0.8312(0.4070)$ & $-0.0009-0.7137(0.4764)$ & $-0.0006-0.4801(0.6318)$ & $-0.0003-0.2633(0.7926)$ \\
\hline $\mathrm{J} 12$ & $0.00070 .2283(0.8196)$ & $0.00050 .2416(0.8094)$ & $0.00020 .1299(0.8968)$ & $0.00010 .0344(0.9726)$ & $0.00010 .0516(0.9589)$ & $-0.0002-0.1399(0.8889)$ & $0.00040 .3760(0.7074)$ & $0.00090 .8170(0.4151)$ \\
\hline J15 & $0.00090 .3175(0.7512)$ & $0.00130 .6725(0.5021)$ & $0.00151 .0189(0.3096)$ & $0.00130 .9950(0.3211)$ & $0.00100 .8684(0.3864)$ & $0.00131 .2678(0.2066)$ & $0.00151 .4986(0.1359)$ & $0.00171 .8264(0.0696)$ \\
\hline J18 & $0.00511 .7525(0.0814)$ & $0.00492 .7302(0.0070) * *$ & $0.00553 .9722(0.0001)$ ** & $0.00433 .5318(0.0005)$ ** & $0.00413 .6084(0.0004) * *$ & $0.00373 .6705(0.0003)$ ** & $0.00394 .1137(0.0001)^{* *}$ & $0.00404 .3781(0.0000) * *$ \\
\hline $\mathrm{J} 21$ & $0.00582 .1123(0.0361) *$ & $0.00593 .2914(0.0012) * *$ & $0.00574 .1264(0.0001) * *$ & $0.00534 .4720(0.0000)$ ** & $0.00504 .6524(0.0000) * *$ & $0.00475 .0338(0.0000)^{* *}$ & $0.00495 .6529(0.0000)^{* *}$ & $0.00526 .5354(0.0000)$ ** \\
\hline$J 24$ & $0.00441 .6310(0.1047)$ & $0.00573 .1778(0.0018) * *$ & $0.00594 .3368(0.0000) * *$ & $0.00584 .8440(0.0000) * *$ & $0.00545 .2365(0.0000) * *$ & $0.00545 .9001(0.0000) * *$ & $0.00566 .7529(0.0000) * *$ & $0.00587 .5855(0.0000) * *$ \\
\hline
\end{tabular}

Table 4 WML Mean Returns (S=1)

This is the peer reviewed version of the following article: Vanstone, B. J., Hahn, T., \& Earea, D. (2020). Industry momentum: an exchange-traded funds approach. Accounting and Finance, which has been published in final form at https://doi.org/10.1111/acfi.12724.

This article may be used for non-commercial purposes in accordance with Wiley Terms and Conditions for Use of Self-Archived Versions. 
A traditional stock momentum paper would present detailed analysis of the 6/0/6 and 6/1/6 portfolios, but Table 3 and Table 4 suggest the 24/0/24 and 24/1/24 should be studied instead. The 24/24 portfolio returns are far more unexpected and far more interesting to a portfolio manager, representing a configuration with high raw returns and reduced turnover. Table 5 presents the Winner, Loser and WML returns for these portfolio subsets.

\begin{tabular}{l|rrrrrr|rrrrrr} 
Portfolio & $\mathrm{J}$ & $\mathrm{S}$ & $\mathrm{K}$ & Mean & $\mathrm{t}$ & $\mathrm{p}$ & $\mathrm{J}$ & $\mathrm{S}$ & $\mathrm{K}$ & Mean & $\mathrm{t}$ & $\mathrm{p}$ \\
\hline Winner & 24 & 0 & 24 & 0.0114 & 10.8345 & 0.0000 & 24 & 1 & 24 & 0.0115 & 11.0361 & 0.0000 \\
Loser & 24 & 0 & 24 & 0.0056 & 5.0557 & 0.0000 & 24 & 1 & 24 & 0.0057 & 5.1904 & 0.0000 \\
WML & 24 & 0 & 24 & 0.0058 & 7.5057 & 0.0000 & 24 & 1 & 24 & 0.0058 & 7.5855 & 0.0000
\end{tabular}

\subsection{Risk}

The returns presented above represent the raw returns to the momentum portfolios. It is clearly of interest if the returns represent abnormal returns, that is returns above the risk free rate and adjusted for market risk.

The risk in this paper present the returns within the Sector ETF momentum portfolios adjusted for risk from the CAPM perspective. Further, for the 24/1/24 portfolio, the January effect and the effect of the GFC are also considered.

As momentum portfolios are overlapping, all regression statistics are corrected using a heteroscedasticity-and-autocorrelation-consistent (HAC) estimate of the variance, as in Cooper et al (Cooper, Guttierrez Jr, and Hameed 2004), specifically using pre-whitening and a lag set to the holding period $(\mathrm{K})$ minus one.

\subsubsection{CAPM}

The CAPM regression model is used to determine whether momentum strategies carry additional risk, with market and risk free returns retrieved from Kenneth French's website (French 2016). 
Table 6 presents the HAC adjusted CAPM risk adjusted returns $\left(\alpha_{p}\right)$ for each portfolio. Here we see the traditional 6/1/6 portfolio has not survived risk adjustment, however, the portfolios formed with longer $\mathrm{J}$ lookback periods have performed well after risk adjustment.

\begin{tabular}{lllllllll} 
& $\mathrm{K} 3$ & $\mathrm{~K} 6$ & $\mathrm{~K} 9$ & $\mathrm{~K} 12$ & $\mathrm{~K} 15$ & $\mathrm{~K} 18$ & $\mathrm{~K} 21$ & $\mathrm{~K} 24$ \\
\hline $\mathrm{J} 3$ & +0.0008 & +0.0056 & +0.0096 & -0.0074 & -0.0314 & -0.0440 & -0.0462 & -0.0549 \\
$\mathrm{~J} 6$ & +0.0105 & +0.0274 & +0.0236 & +0.0063 & -0.0062 & -0.0054 & -0.0037 & -0.0061 \\
$\mathrm{~J} 9$ & +0.0074 & +0.0003 & -0.0115 & -0.0283 & -0.0352 & -0.0420 & -0.0450 & -0.0423 \\
$\mathrm{~J} 12$ & +0.0017 & +0.0011 & -0.0024 & -0.0088 & -0.0133 & -0.0253 & -0.0191 & -0.0133 \\
$\mathrm{~J} 15$ & +0.0032 & +0.0075 & +0.0125 & +0.0122 & +0.0090 & +0.0141 & +0.0170 & +0.0200 \\
$\mathrm{~J} 18$ & +0.0157 & +0.0306 & $+0.0538^{*}$ & $+0.0566 *$ & $+0.0684 *$ & $+0.0659 *$ & +0.0718 & +0.0815 \\
$\mathrm{~J} 21$ & +0.0198 & $+0.0411 *$ & $+0.0605 * *$ & $+0.0753 * *$ & $+0.0851 * *$ & $+0.0835 * *$ & $+0.0940 * *$ & $+0.1111 * *$ \\
$\mathrm{~J} 24$ & +0.0168 & $+0.0417 *$ & $+0.0649 * *$ & $+0.0844 * *$ & $+0.0916 * *$ & $+0.0972 * *$ & $+0.1136 * *$ & $+0.1295 * *$ \\
Table 6 CAPM Risk-adjusted returns $(\mathrm{S}=1)$ & & & & & &
\end{tabular}

Table 7 and Table 8 present the same portfolios as in Table 6. Table 7 and Table 8 break up the portfolio returns to those achieved pre- and post-2008 to give additional insight into robustness of results. We find that the longer $\mathrm{J}$ and $\mathrm{K}$ portfolios survive CAPM risk adjustment both pre and post 2008, and the risk adjusted returns again monotonically increase with increasing $\mathrm{J}$ and $\mathrm{K}$ specifications.

\begin{tabular}{lllllllll} 
& K3 & K6 & K9 & K12 & K15 & K18 & K21 & K24 \\
\hline J3 & +0.0124 & +0.0176 & +0.0056 & -0.0123 & -0.0382 & -0.0478 & -0.0584 & -0.0527 \\
J6 & +0.0234 & +0.0381 & +0.0316 & +0.0208 & +0.0103 & +0.0095 & +0.0172 & +0.0227 \\
J9 & +0.0113 & +0.0092 & -0.0040 & -0.0195 & -0.0226 & -0.0237 & -0.0185 & -0.0137 \\
J12 & +0.0075 & +0.0041 & -0.0110 & -0.0146 & -0.0094 & -0.0081 & +0.0038 & +0.0137 \\
J15 & +0.0109 & +0.0040 & -0.0023 & +0.0098 & +0.0182 & +0.0245 & +0.0276 & +0.0302 \\
J18 & +0.0140 & +0.0209 & +0.0488 & +0.0599 & +0.0718 & +0.0691 & +0.0736 & +0.0749 \\
J21 & +0.0183 & +0.0400 & +0.0582 & +0.0740 & +0.0827 & +0.0781 & +0.0820 & $+0.0882 *$ \\
J24 & +0.0201 & +0.0442 & $+0.0618 *$ & $+0.0821 *$ & $+0.0843 *$ & $+0.0822 *$ & $+0.0856 *$ & $+0.0991 *$ \\
Table 7 Pre-2008 CAPM Risk-adjusted returns $(\mathrm{S}=1)$ & & & &
\end{tabular}

\begin{tabular}{lllllllll} 
& K3 & K6 & K9 & K12 & K15 & K18 & K21 & K24 \\
\hline 3 & -0.0083 & -0.0079 & +0.0075 & +0.0397 & -0.0520 & -0.0636 & +0.0405 & +0.0805 \\
6 & -0.0110 & +0.0170 & +0.0243 & +0.0003 & -0.0916 & -0.0179 & +0.0634 & +0.0829 \\
9 & +0.0035 & +0.0160 & +0.0017 & -0.0298 & -0.0891 & $-0.1064 * *$ & -0.0794 & +0.0152 \\
12 & +0.0030 & +0.0172 & +0.0582 & +0.0757 & +0.0027 & -0.0400 & +0.0189 & +0.1177 \\
15 & -0.0006 & +0.0365 & +0.0778 & +0.0800 & +0.0068 & +0.0425 & $+0.1402 *$ & $+0.2253 * *$
\end{tabular}




$\begin{array}{lllllllll}18 & +0.0289 * & +0.0637 * & +0.0810 * & +0.1022 * & +0.1267 * & +0.1632 * * & +0.2269 * * & +0.3561 * * \\ 21 & +0.0216 & +0.0439 & +0.0505 & +0.0875 & +0.0860 & +0.0993 & +0.1983 * & +0.3319 * * \\ 24 & +0.0141 & +0.0423 & +0.0733 & +0.1139 * & +0.1301 & +0.1726 * & +0.3030 * * & +0.4049 * *\end{array}$

Table 8 Post-2008 CAPM Risk-adjusted returns ( $\mathrm{S}=1$ )

We conclude that the longer specification $\mathrm{J}$ and $\mathrm{K}$ Sector ETF portfolios show positive, statistically significant excess returns after adjusting for risk, both pre and post GFC.

The 24/1/24 portfolio is clearly the portfolio to analyse further. It represents the ideal case of a low turnover, easily implemented investment strategy. A large number of simulations was performed to identify this portfolio combination, however, the results retain statistical significance even after applying a Bonferroni correction.

The remainder of the risk section of this paper focuses on the 24/1/24 portfolio.

\subsubsection{January Effect}

It is common to test for the January effect when evaluating abnormal returns to investment strategies. The January effect describes a seasonal increase in stock prices during the month of January, often attributed to year end tax motivated selling. Market and risk free returns are retrieved from Kenneth French’s website (French 2016).

The HAC adjusted January Effect regression showed a statistically significant $\alpha=0.1307$ ( $\mathrm{p}=0.0014$ ), and no significant loadings on any of the $\beta$ coefficients, indicating the $24 / 1 / 24$ portfolio returns are significant even after accounting for the January Effect.

The mean return for all January months was 0.128 , while the mean return for non-January months was 0.140 . We conclude there is no January effect present in the 24/1/24 portfolio.

\subsubsection{GFC Effect}

The GFC period represented a time of extreme stress for the global markets. As a response to the crisis, regulators around the world implemented short-selling bans. For managers 
implementing momentum portfolios, this ban would have essentially prevented short positions. In the US, these short bans were implemented during August and September 2008 (Bohl, Klein, and Siklos 2014).

Market and risk free returns are retrieved from Kenneth French’s website (French 2016)., and a three factor dummy variable is used for the GFC condition to isolate returns pre-GFC, during the GFC short selling ban, and post-GFC.

The HAC adjusted GFC regression showed a statistically significant $\alpha=0.1059(\mathrm{p}=0.0208)$. It also showed a significant loading on the GFC dummy variable $\beta_{g f c}=0.1259(\mathrm{p}=0.0431)$, indicating returns during the GFC were different from returns both pre and post GFC. The results also showed that the returns in the post-GFC period were not statistically different from the returns in the pre-GFC period.

Prior work on isolating the effect of the GFC period on stock momentum portfolios has shown the GFC to have a particularly significantly negative effect on returns (Vanstone and Hahn 2015). This does not appear to have been the case within the Sector ETF momentum portfolios.

\section{Conclusions}

Sector ETF momentum is very different in character to stock momentum. In a typical stock momentum portfolio, the abnormal returns area of the portfolio space is characterized by intermediate $\mathrm{J}$ and $\mathrm{K}$ values, with the $6 / 6$ portfolio normally representing the idealized portfolio. As 6/6 is the expected abnormal returns area for stock momentum portfolios, and we see a significant raw return for the 6/6 sector ETF momentum portfolios, it seems likely that some portfolio managers are already managing ETF momentum portfolios the same way 
as they manage stock momentum portfolios. However, in sector ETF momentum portfolios, significant raw returns at the $6 / 6$ portfolio do not survive risk adjustment.

The motivation of this paper was to investigate the investment performance of industry momentum strategies using ETFs, and to determine whether the beneficial aspects of industry momentum as described by M\&G could be captured using Sector ETFs with a substantially reduced turnover and implementation cost.

Overall we find support for Sector ETF momentum. There are pockets of true outperformance that cluster in longer specifications of $\mathrm{J}$ and $\mathrm{K}$, and these are clearly exposed in this research. Our results suggest that the abnormal returns portfolio space in Sector ETF portfolios is better characterized by longer timeframe $\mathrm{J}$ and $\mathrm{K}$ values, with the $24 / 1 / 24$ portfolio representing the ideal portfolio. Similar to M\&G, we find the portfolio returns are predominantly driven by the winner portfolio. The 24/1/24 portfolio is robust, has low turnover and statistically significant abnormal returns after adjusting for market risk. The 24/1/24 portfolio does not derive its excess returns from the January Effect, and it did not suffer during the GFC.

Indeed, implementing an industry momentum portfolio approach using Sector ETFs would appear to be a profitable, untapped opportunity for portfolio managers.

\section{Future Work}

There is an increasing focus on both momentum investing and Exchange Traded Funds in the funds management space. There are now ETFs available over a vast range of indices, stocks and commodities, raising the prospect of moving momentum from a traditional stock investment anomaly to a much larger universe of investable products. 
The next step for this work is to investigate the idea of global momentum portfolios, using a combination of international index, sector and industry ETFs.

\section{Acknowledgements}

The data used in this research was supplied by Bloomberg. The authors also gratefully acknowledge Professor Tom Smith for his helpful comments and suggestions. 


\section{Bibliography}

Andreu, L., L. Swinkels, and L. Tjong-A-Tjoe, 2013, Can exchange traded funds be used to exploit industry and country momentum?, Financial Markets and Portfolio Management 27, 127148.

Asness, C., 1994, Variables that explain stock returns, (University of Chicago.

Asness, C., J. Liew, and R. Stevens, 1997, Parallels between the cross-sectional predictability of stock and country returns, The Journal of Portfolio Management 23, 79-87.

Asness, C., T. Moskowitz, and L. H. Pedersen, 2013, Value and Momentum Everywhere, Journal of Finance 68, 929-985.

Avramov, D., and R. Wermers, 2006, Investing in mutual funds when returns are predictable, Journal of Financial Economics 81, 339-377.

Beracha, E., and H. Skiba, 2011, Momentum in Residential Real Estate, Journal of Real Estate Finance \& Economics 43, 299-320.

Bhojraj, S., and B. Swaminathan, 2006, Macromomentum: returns Predictability in International Equity Indices, Journal of Business 79, 429-451.

Blitz, D., and P. V. Vliet, 2008, Global Tactical Cross-Asset Allocation: Applying Value and Momentum across Asset Classes, Journal of Portfolio Management 35, 23-38.

Bohl, M. T., A. C. Klein, and P. L. Siklos, 2014, Short-selling bans and institutional investors' herding behaviour: Evidence from the global financial crisis, International Review of Financial Analysis 33, 262-269.

Boni, L., and K. L. Womack, 2006, Analysts, Industries, and Price Momentum, The Journal of Financial and Quantitative Analysis 41, 85-109.

Breloer, B., H. Scholz, and M. Wilkens, 2014, Performance of international and global equity mutual funds: Do country momentum and sector momentum matter?, Journal of Banking \& Finance 43, 58-77.

Burch, T. R., and B. Swaminathan, Are Institutions Momentum Traders? , available from https://ssrn.com/abstract $=291643$

Chan, K., A. Hameed, and W. Tong, 2000, Profitability of momentum strategies in the international equity markets, Journal of Financial and Quantitative Analysis 35, 153-172.

Chen, Z., Y. Wu, and H. Zhang, Productivity, Asset Returns, and International Index Momentum, available from https://ssrn.com/abstract=1106807

Chui, A. C. W., S. Titman, and K. C. J. Wei, 2003, Intra-industry momentum: the case of REITs, Journal of Financial Markets 6, 363-387.

Cooper, M. J., R. C. Guttierrez Jr, and A. Hameed, 2004, Market States and Momentum, The Journal of Finance 59, 1345-1365.

De Jong, J. C., and S. G. Rhee, 2008, Abnormal returns with momentum/contrarian strategies using exchange-traded funds, Journal of Asset Management 9, 289-299.

Demirer, R., D. Lien, and H. Zhang, 2015, Industry herding and momentum strategies, Pacific-Basin Finance Journal 32, 95-110.

Dimkpah, Y., and C. Ngassam, 2013, The Rise in Equity Exchange Traded Funds (ETFs): The Case of Momentum?, Academy of Accounting and Financial Studies Journal 17, 95.

Dolvin, S., and J. Kirby, 2011, Momentum Trading in Sector ETFs, The Journal of Index Investing 2, 5057. 
Du, D., and K. Denning, 2005, Industry momentum and common factors, Finance Research Letters 2, 107-124.

Du, D., and B. Watkins, 2007, When competing momentum hypotheses really do not compete: How the sources of momentum profits change through time, Journal of Economics and Business 59, 2007.

French, K., Current Research Returns, available from http://mba.tuck.dartmouth.edu/pages/faculty/ken.french/data library.html

Griffin, J. M., S. Ji, and J. S. Martin, 2004, Global Momentum Strategies: A Portfolio Perspective, The Journal of Portfolio Management 31, 23-39.

Griffin, J. M., X. Ji, and J. S. Martin, 2003, Momentum Investing and Business Cycle Risk: Evidence from Pole to Pole, The Journal of Finance 58, 2515-2547.

Gupta, K., S. Locke, and F. Scrimgeour, 2010, International comparison of returns from conventional, industrial and 52-week high momentum strategies, Journal of International Financial Markets, Institutions and Money 20, 423-435.

Jegadeesh, N., and S. Titman, 1993, Returns to buying winners and selling losers: Implications for stock market efficiency, Journal of Finance 48, 65-91.

Jostova, G., S. Nikolova, A. Philipov, and C. W. Stahel, 2013, Momentum in Corporate Bond Returns, The Review of Financial Studies 26, 1649-1693.

Kalotychou, E., S. K. Staikouras, and G. Zhao, 2014, The role of correlation dynamics in sector allocation, Journal of Banking \& Finance 48, 1-12.

Kaminsky, G., R. K. Lyons, and S. L. Schmukler, 2004, Managers, investors, and crises: mutual fund strategies in emerging markets, Journal of International Economics 64, 113-134.

Li, B., T. Stork, D. Chai, M. S. Ee, and H. N. Ang, 2014, Momentum effect in Australian Equities: Revists, armed with short-selling ban and risk factors, Pacific-Basin Finance Journal 27, 19-31.

Madura, J., and M. K. Bers, 2002, The performance persistence of foreign closed-end funds, Review of Financial Economics 11, 263-285.

Madura, J., and T. Ngo, 2008, Pricing Behaviour of Exchange Traded Funds, Journal of Economics and Finance 32, 1-23.

Menkhoff, L., L. Sarno, M. Schmeling, and A. Schrimpf, 2012, Currency momentum strategies, Journal of Financial Economics 106, 660-684.

Menkhoff, L., and M. Schmeling, Industry Momentum and Behavioral Limits to Arbitrage, available from 10.1.1.194.8325.pdf at citseerx.ist.psu.edu

Miffre, J., and G. Rallis, 2007, Momentum Strategies in Commodity Futures Markets, Journal of Banking \& Finance $31,1863-1886$.

Moskowitz, T. J., and M. Grinblatt, 1999, Do Industries Explain Momentum?, The Journal of Finance 54, 1249-1290.

Naranjo, A., and B. Porter, 2010, Risk factor and industry effects in the cross-country comovement of momentum returns, Journal of International Money and Finance 29, 275-299.

Narayan, P. K., H. A. Ahmed, S. S. Sharma, and P. K. P., 2014, How profitable is the Indian stock market?, Pacific-Basin Finance Journal 30, 44-61.

Nijman, T., L. Swinkels, and M. Verbeek, 2004, Do countries or industries explain momentum in Europe?, Journal of Empirical Finance 11, 461-481.

O'Neal, E., 2000, Industry momentum and sector mutual funds, Financial Analysts Journal 56, 37-49.

Okunev, J., and D. White, 2003, Do momentum-based strategies still work in foreign currency markets?, Journal of Financial and Quantitative Analysis 38.

Rouwenhorst, K. G., 1998, International Momentum Strategies, Journal of Finance 53, 267-284.

Rouwenhorst, K. G., 1999, Local return factors and turnover in emerging stock markets, Journal of Finance 54, 1439-1464. 
Safieddine, A., and R. Sonti, 2007, Momentum and industry growth, Review of Financial Economics $16,203-215$.

Sapp, T., 2011, The 52-week high, momentum, and predicting mutual fund returns, Review of Quantitative Finance and Accounting 37, 149-179.

Scowcroft, A., and J. Sefton, 2005, Understanding Momentum, Financial Analysts Journal 61.

State Street Global Advisors, State Street Global Advisors: SPDR, available from https://www.spdrs.com/

Stevenson, S., 2002, Momentum effects and mean reversion in real estate securities, Journal of Real Estate 23, 47-64.

Tse, Y., 2015, Momentum strategies with stock index exchange-traded funds, The North American Journal of Economics and Finance 33, 134-148.

Vanstone, B., and T. Hahn, 2015, Australian momentum: performance, capacity and the GFC effect, Accounting \& Finance http://dx.doi.org/10.1111/acfi.12140.

Velissaris, J., 2010, Diversified Statistical Arbitrage: Dynamically combining mean reversion and momentum investment strategies, Submitted for Review to the National Association of Active Investment Managers. 